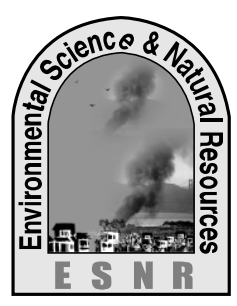

\title{
Residual Effect of Green Manure on the Growth and Yield of BRRI dhan28
}

\author{
M. R. Islam ${ }^{1}$, Z. Ryhana ${ }^{1}$, M. A. Hoque ${ }^{1}$, A. Huda ${ }^{2}$ and M. L. N. Begum ${ }^{3}$ \\ ${ }^{1}$ Department of Soil Science, \\ Bangaldesh Agricultural University, Mymensingh-2202 \\ ${ }^{2}$ Department of Soil Science, \\ Sylhet Agricultural University, Sylhet-3100 \\ ${ }^{3}$ Practical Skill Development Training Department, \\ Proshika, Mirpur-2, Dhaka-1216 \\ * Corresponding author: rafiqss69@bau.edu.bd
}

\begin{abstract}
Green manuring is a promising technology to enrich soils with organic matter especially with nitrogen to boost up rice production. An experiment was, therefore, conducted at the Soil Science Field Laboratory of Bangladesh Agricultural University, Mymensingh during boro season of 2013 to evaluate the residual effect of Sesbania green manure on the growth and yield of BRRI dhan28. There were nine treatments laid out in a Randomized Complete Block Design (RCBD) with three replications. The results demonstrate that the treatment $\mathrm{T}_{8}$ containing $75 \%$ recommended dose of nitrogen (RDN) and green manure incorporated at 70 DAS produced the highest grain yield of $4967 \mathrm{~kg} \mathrm{ha}^{-1}$ and straw yield of $5359 \mathrm{~kg} \mathrm{ha}^{-1}$. The lowest grain yield $\left(4208 \mathrm{~kg} \mathrm{ha}^{-1}\right)$ and straw yield $\left(4352 \mathrm{~kg} \mathrm{ha}^{-1}\right)$ were recorded for the treatment $\mathrm{T}_{1}$ (GM incorporated at $40 \mathrm{DAS}+50 \% \mathrm{RD}$ of NF). Green manure exerted significant residual effect on grain $\mathrm{N}$ uptake, straw $\mathrm{N}$ uptake and total $\mathrm{N}$ uptake of BRRI dhan28. The residual effect of green manure was the higher in producing rice yields in treatments with the application of $75 \%$ of recommended $\mathrm{N}$ fertilizer with green manure incorporated at 50 or 70 DAS.
\end{abstract}

Key words: BRRI dhan28, Green manure, Residual effect, Yield

\section{Introduction}

Rice is the most important agricultural produce and the main staple food in Bangladesh. Total rice production in Bangladesh was 31.9 Mt (DAE, 2010). But it is insufficient to meet the demand of food requirement for our increasing population. Besides this, soil fertility depletion is a major constraint for higher crop yield in Bangladesh. To overcome soil fertility constraint, efficient soil fertility and fertilizer management are important. Organic matter contributes to soil fertility and productivity through its positive effect on the physical, chemical and biological properties of the soil. But the organic matter content in many of our soils has been seriously depleted due to intensive cropping with modern varieties, very little use of crop residues, little or no use of organic manures, green manure etc. As a result, soil fertility, in general, has been degraded. According to Fertilizer Recommendation Guide BARC (2012), a good soil should have at least $2.5 \%$ organic matter but in Bangladesh, most soils have less than $1 \%$ organic matter. Losses of soil organic matter can be replenished by the application of organic manures (Glaser et al., 2001). This undesirable consequence can be addressed properly by using organic sources like compost, FYM, cowdung, oilcake, crop residues, other organic wastes, leaf manuring and green manure. Green manuring is the most important one amongst all the organic manures. It is a good management practice in agricultural production, because it can improve soil fertility and quality (Lee et al., 2010) and also supply N, a primary limiting nutrient for crops (Pypersa et al., 2005; Elfstrand et al., 2007). Although many green manure crops are available, the $\mathrm{N}_{2}$-fixing leguminous crop Dhaincha (Sesbania aculeata) is particularly important because it can fix $56.2-150 \mathrm{~kg} \mathrm{ha}^{-1}$ of nitrogen (Bin, 1983). It has also been reported that green manuring provides a substantial amount of nutrients for the next crop (Nur-E-Elahi, 1991; BRRI, 1998). Incorporation of green manure crops into the soil has been shown to increase organic carbon, total nitrogen and crop yields ( $\mathrm{Gu}$ and Wen, 1980). It has also been reported that green manuring, besides its role of supplying plant nutrition, renders the crop more tolerant to disease and insects and prevents soil erosion (Dreyfus et al., 1985; Evans and Rotar, 1986; Singhabutra et al., 1987).

Due to residual effect the current increase in yield caused by fertilizer applied in earlier season and the residual effect can vary from year to year (Warren, 1992). Moreover, residual effect of green manure helps in improving physical, chemical and biological properties of the soil. The residual effect of green manure provide the most effective way to improve the nitrogen supply for succeeding crops (ThorupKristensen et al., 2003). From the economic and environmental point of view, green manuring with locally available resources is going to offer a great opportunity since the chemical fertilizers are getting costly day by day. It has been shown that organic matter cycling is related to the agricultural potential of soils (Tiessen et al., 1994). It is evident that the residual effect of green manure along with the application of recommended chemical fertilizers may ensure adequate supply of nutrients especially nitrogen to the transplanted rice over the entire growing season for better plant growth with higher grain production. Therefore, the present study was undertaken to evaluate the residual effect of Sesbania green manure on the growth and yield of BRRI dhan 28 and to investigate the residual effect of green manure on $\mathrm{N}$ uptake by BRRI dhan 28 .

\section{Materials and Methods}

Experimental site and soil 
The experiment was carried out at the Soil Science Field Laboratory of Bangladesh Agricultural University, Mymensingh during boro season of 2013. The experimental soil belongs to the Sonatala series under the AEZ of Old Brahmaputra Floodplain. The soil was silt loam in texture having $\mathrm{pH} 6.39$, organic matter content $2.5 \%$, total $\mathrm{N} 0.168 \%$, available P $4.76 \mathrm{ppm}$, exchangeable K $0.13 \mathrm{meq}^{-1} 100 \mathrm{~g}$ soil, available S 12.47 ppm, exchangeable $\mathrm{Na} 0.297 \mathrm{meq}^{-1} 100 \mathrm{~g}$ soil, exchangeable Ca $6.09 \mathrm{meq}^{-1} 100 \mathrm{~g}$ soil and CEC 14.92 $\mathrm{meq}^{-1} 100 \mathrm{~g}$ soil.

\section{Treatments}

The experiment was laid out in a Randomized Complete Block Design (RCBD) with nine treatments each replicated thrice. The treatments were $\mathrm{T}_{0}$ (No $\mathrm{GM}+$ $100 \% \mathrm{RDN}), \mathrm{T}_{1}$ (GM incorporated at $40 \mathrm{DAS}+50 \%$ RDN) $\mathrm{T}_{2}$ (GM incorporated at $\left.40 \mathrm{DAS}+75 \% \mathrm{RDN}\right), \mathrm{T}_{3}$ $(\mathrm{GM}$ incorporated at $50 \mathrm{DAS}+50 \% \mathrm{RDN}), \mathrm{T}_{4}(\mathrm{GM}$ incorporated at $50 \mathrm{DAS}+75 \% \mathrm{RDN}), \mathrm{T}_{5}(\mathrm{GM}$ incorporated at $60 \mathrm{DAS}+50 \% \mathrm{RDN}), \mathrm{T}_{6}(\mathrm{GM}$ incorporated at $60 \mathrm{DAS}+75 \% \mathrm{RDN}), \mathrm{T}_{7}(\mathrm{GM}$ incorporated at $70 \mathrm{DAS}+50 \% \mathrm{RDN})$ and $\mathrm{T}_{8}(\mathrm{GM}$ incorporated at $70 \mathrm{DAS}+75 \% \mathrm{RDN})$. Where, $\mathrm{GM}=$ Green manure and RDN $=$ Recommended dose of nitrogen.

\section{Seedling transplanting}

BRRI dhan28, a high yielding variety of rice was used as a test crop. Thirty five day-old seedlings were carefully uprooted from a seedling nursery bed and transplanted in the plots maintaining a spacing of $20 \mathrm{~cm}$ x $20 \mathrm{~cm}$. Three seedlings were transplanted in each hill.

\section{Green manuring crop}

In the previous rice crop Sesbania aculeata was used as pre-rice green manuring crop. This green manuring crop was incorporated into the soil at 40, 50, 60 and 70 DAS as per treatments.

\section{Application of fertilizers}

The full amount of Triple Super Phosphate (TSP), Muriate of Potash (MoP) and gypsum @ 120, 70 and 50 $\mathrm{kg} \mathrm{ha}^{-1}$, respectively was applied at the time of final land preparation. The recommended rate of urea used was $180 \mathrm{~kg} \mathrm{ha}^{-1}$. Two levels of $\mathrm{N}$ fertilizer (urea) including $50 \%$ and $75 \%$ of the recommended dose were applied. The $\mathrm{N}$ fertilizer (urea) was applied in three equal splits; the first installment at 15 days after transplanting (DAT), the second installment at 30 DAT i.e. at maximum tillering stage and the third installment at 45 DAT i.e. at panicle initiation stage or booting stage of rice.

\section{Intercultural operations}

Irrigation was provided to the plots from deep tube well to maintain 5-6 cm water during the growing period of the crop. Some obnoxious weeds were controlled by uprooting and removing two times from the field.

\section{Harvesting}

The crop was harvested at maturity. The grain yield was obtained on $14 \%$ moisture basis while the straw yield was recorded on sun dry basis. Five hills were selected randomly from each plot and data on yield components including plant height, effective tillers per hill, panicle length, grains panicle ${ }^{-1}$ and 1000-grain weight were recorded.

\section{Determination of $\mathrm{N}$ in plant samples}

The $\mathrm{N}$ content in rice grain and straw was determined by Semi-micro Kjeldahl method. Nitrogen uptake was the calculated from $\mathrm{N}$ content and yield data.

\section{Statistical analysis}

The analysis of variance for various crop characters and also for various nitrogen concentrations and nitrogen uptake was done following the F-test. Mean comparisons of the treatments were made by the Duncan's New Multiple Range Test (DMRT) (Gomez and Gomez, 1984).

\section{Results and Discussion}

\section{Growth and yield attributes of BRRI dhan 28}

Growth and yield contributing characters such as plant height, effective tillers hill ${ }^{-1}$, panicle length and filled grains panicle ${ }^{-1}$ of BRRI dhan 28 showed insignificant response to residual effect of green manuring with Sesbania along with different doses of $\mathrm{N}$-fertilizer (Table 1$)$. The tallest plant $(87.80 \mathrm{~cm})$ was recorded in the treatment $\mathrm{T}_{8}(\mathrm{GM}$ incorporated at $70 \mathrm{DAS}+75 \%$ RDN) and the shortest plant $(69.47 \mathrm{~cm})$ was obtained in the treatment $\mathrm{T}_{2}$ (GM incorporated at $40 \mathrm{DAS}+75 \%$ RDN). The highest number of effective tillers hill $^{-1}$ (15.67) was found in $\mathrm{T}_{2}$ (GM incorporated at $40 \mathrm{DAS}+$ $75 \% \mathrm{RDN}$ ) and the lowest number of effective tillers hill $^{-1}$ (11.67) was found in $\mathrm{T}_{5}$ (GM incorporated at 60 DAS $+50 \%$ RDN). The highest panicle length (23.15 $\mathrm{cm})$ was found in $\mathrm{T}_{5}$ (GM incorporated at $60 \mathrm{DAS}+$ $50 \% \mathrm{RDN})$ while the lowest panicle length $(21 \mathrm{~cm})$ was observed in $\mathrm{T}_{0}(\mathrm{No} \mathrm{GM}+100 \% \mathrm{RDN})$.

The highest number of filled grains panicle ${ }^{-1}$ was found both in $\mathrm{T}_{1}$ (GM incorporated at $\left.40 \mathrm{DAS}+50 \% \mathrm{RDN}\right)$ and $\mathrm{T}_{8}$ (GM incorporated at $\left.70 \mathrm{DAS}+75 \% \mathrm{RDN}\right)$ treatments and the lowest was found in $\mathrm{T}_{7}(\mathrm{GM}$ incorporated at $70 \mathrm{DAS}+50 \% \mathrm{RDN})$.

\section{Grain yield}

Grain yield of BRRI dhan28 responded insignificantly to the residual effect of green manure in combination with $\mathrm{N}$ fertilizer (Table 2). The highest grain yield $\left(4967 \mathrm{~kg} \mathrm{ha}^{-1}\right)$ was obtained in the treatment $\mathrm{T}_{8}$ (GM incorporated at $70 \mathrm{DAS}+75 \% \mathrm{RDN})$ and the lowest grain yield $\left(4208 \mathrm{~kg} \mathrm{ha}^{-1}\right)$ was obtained in the treatment $\mathrm{T}_{0}$ (No GM $+100 \%$ RDN). The $\mathrm{T}_{8}$ and $\mathrm{T}_{4}$ showed 18.01 and $18.03 \%$ grain yield increase over control, respectively (Table 2 and Fig. 1). Moreover, it was shown that application of $75 \%$ recommended $\mathrm{N}$ with Sesbania green manure produced higher grain yield than that with $100 \%$ recommended $\mathrm{N}$ when the green manure was incorporated into the soil at 50 or 70 DAS. These results are in consistent with the findings of Hossain (2013) and Jahan (2014) who concluded that application of green manure can reduce $25 \%$ of recommended $\mathrm{N}$ in rice cultivation. 
These results are also in agreement with Paturde and Patankar (1998); Dekamedhi and Medhi (2000); Singh et al. (2006); Ghosh (2007); Choudhury (2009). The grain yields obtained from different treatments may be ranked in the order of decreasing trend $\mathrm{T}_{8}>\mathrm{T}_{4}>\mathrm{T}_{2}>\mathrm{T}_{5}>$ $\mathrm{T}_{6}>\mathrm{T}_{3}>\mathrm{T}_{7}>\mathrm{T}_{1}>\mathrm{T}_{0}$.

\section{Straw yield}

Straw yield of BRRI dhan28 did not respond significantly under the study. The numerical variation shows the highest straw yield $\left(5359 \mathrm{~kg} \mathrm{ha}^{-1}\right)$ with $23.13 \%$ yield increase over control (Table 2 and Fig. 1) as recorded in the treatment $\mathrm{T}_{8}(\mathrm{GM}$ incorporated at 70 $\mathrm{DAS}+75 \% \mathrm{RDN})$ and the lowest straw yield $(4359 \mathrm{~kg}$ $\mathrm{ha}^{-1}$ ) as recorded in the treatment $\mathrm{T}_{0}$ (No GM $+100 \%$ RDN). The treatments may be ranked in the order of decreasing straw yield as $\mathrm{T}_{8}>\mathrm{T}_{4}>\mathrm{T}_{2}>\mathrm{T}_{6}>\mathrm{T}_{7}>\mathrm{T}_{3}>\mathrm{T}_{5}>$ $\mathrm{T}_{1}>\mathrm{T}_{0}$.

\section{Nitrogen uptake by grain}

A significant variation in $\mathrm{N}$ uptake by grain of BRRI dhan28 was observed due to residual effect of green manure in combination with $\mathrm{N}$ fertilizer (Table 3 ). The highest $\mathrm{N}$ uptake $\left(64.19 \mathrm{~kg} \mathrm{ha}^{-1}\right)$ by grain was recorded in the treatment $\mathrm{T}_{4}(\mathrm{GM}$ incorporated at $50 \mathrm{DAS}+75 \%$ $\mathrm{RDN})$. The lowest $\mathrm{N}$ uptake $\left(44.62 \mathrm{~kg} \mathrm{ha}^{-1}\right)$ by grain was obtained in the treatment $\mathrm{T}_{1}(\mathrm{GM}$ incorporated at 40 $\mathrm{DAS}+50 \% \mathrm{RDN})$. The results are in agreement with
Medhi et al. (1996); Dekamedhi and Medhi (2000); Kumar et al. (2012); Hossain (2013) who reported that application of green manure produced increased $\mathrm{N}$ uptake by rice. The $\mathrm{N}$ uptake in grain may be ranked in the order of $T_{4}>T_{8}>T_{2}>T_{0}>T_{6}>T_{3}>T_{7}>T_{5}>T_{1}$.

\section{Nitrogen uptake by straw}

The $\mathrm{N}$ uptake by straw of BRRI dhan 28 was influenced significantly due to residual effect of green manure along with urea-N (Table 3). The highest $\mathrm{N}$ uptake (42.42 $\left.\mathrm{kg} \mathrm{ha}^{-1}\right)$ by straw was obtained in the treatment $\mathrm{T}_{8}$ (GM incorporated at $70 \mathrm{DAS}+75 \% \mathrm{RDN})$. The treatment $\mathrm{T}_{5}$ (GM incorporated at $60 \mathrm{DAS}+50 \% \mathrm{RDN})$ produced the lowest $\mathrm{N}$ uptake $\left(25.94 \mathrm{~kg} \mathrm{ha}^{-1}\right)$ in rice straw. The treatments may be ranked in the order of $\mathrm{T}_{8}>\mathrm{T}_{6}>\mathrm{T}_{4}>\mathrm{T}_{2}>$ $\mathrm{T}_{3}>\mathrm{T}_{0}>\mathrm{T}_{7}>\mathrm{T}_{1}>\mathrm{T}_{5}$ in terms of $\mathrm{N}$ content in straw.

\section{Total $N$ uptake}

There was a significant effect of green manure residues and urea-N on total $\mathrm{N}$ uptake by BRRI dhan28 (Table $3)$. The highest total $\mathrm{N}$ uptake $\left(102.81 \mathrm{~kg} \mathrm{ha}^{-1}\right)$ was recorded in the treatment $\mathrm{T}_{4}(\mathrm{GM}$ incorporated at 50 DAS $+75 \%$ RDN $)$. The lowest total $\mathrm{N}$ uptake $(72.32 \mathrm{~kg}$ $\left.\mathrm{ha}^{-1}\right)$ was obtained in the treatment $\mathrm{T}_{1}(\mathrm{GM}$ incorporated at $40 \mathrm{DAS}+50 \% \mathrm{RDN})$. The total $\mathrm{N}$ uptake obtained from different treatments may be ranked in the order of $\mathrm{T}_{4}>\mathrm{T}_{8}>\mathrm{T}_{6}>\mathrm{T}_{2}>\mathrm{T}_{0}>\mathrm{T}_{3}>\mathrm{T}_{7}>\mathrm{T}_{5}>\mathrm{T}_{1}$.

Table 1. Residual effects of green manure and different levels of nitrogen on the growth and yield components of BRRI dhan28

\begin{tabular}{|c|c|c|c|c|}
\hline Treatments & $\begin{array}{l}\text { Plant } \\
\text { height } \\
(\mathbf{c m})\end{array}$ & $\begin{array}{c}\text { Effective tillers } \\
\text { hill }^{-1} \\
\text { (No.) }\end{array}$ & $\begin{array}{c}\text { Panicle } \\
\text { length }(\mathrm{cm})\end{array}$ & $\begin{array}{l}\text { Filled grains } \\
\text { panicle }^{-1} \\
\text { (No.) }\end{array}$ \\
\hline $\mathrm{T}_{0}(\mathrm{No} \mathrm{GM}+100 \% \mathrm{RDN})$ & 83.50 & 14.00 & 21.00 & 107 \\
\hline $\begin{array}{l}\mathrm{T}_{1}(\mathrm{GM} \text { incorporated at } 40 \mathrm{DAS}+ \\
50 \% \mathrm{RDN})\end{array}$ & 82.33 & 12.33 & 23.08 & 111 \\
\hline $\begin{array}{l}\mathrm{T}_{2}(\mathrm{GM} \text { incorporated at } 40 \mathrm{DAS}+ \\
75 \% \mathrm{RDN})\end{array}$ & 69.47 & 15.67 & 22.53 & 103 \\
\hline $\begin{array}{l}\mathrm{T}_{3}(\mathrm{GM} \text { incorporated at } 50 \mathrm{DAS}+ \\
50 \% \mathrm{RDN})\end{array}$ & 83.26 & 13.67 & 23.06 & 97 \\
\hline $\begin{array}{l}\mathrm{T}_{4}(\mathrm{GM} \text { incorporated at } 50 \mathrm{DAS}+ \\
75 \% \mathrm{RDN})\end{array}$ & 87.27 & 12 & 22.19 & 97 \\
\hline $\begin{array}{l}\mathrm{T}_{5}(\mathrm{GM} \text { incorporated at } 60 \mathrm{DAS}+ \\
50 \% \mathrm{RDN})\end{array}$ & 69.60 & 11.67 & 23.15 & 110 \\
\hline $\begin{array}{l}\mathrm{T}_{6}(\mathrm{GM} \text { incorporated at } 60 \mathrm{DAS}+ \\
75 \% \mathrm{RDN})\end{array}$ & 84.53 & 13 & 23.09 & 108 \\
\hline $\begin{array}{l}\mathrm{T}_{7}(\mathrm{GM} \text { incorporated at } 70 \mathrm{DAS}+ \\
50 \% \mathrm{RDN})\end{array}$ & 82.56 & 13.67 & 22.00 & 92 \\
\hline $\begin{array}{l}\mathrm{T}_{8}(\mathrm{GM} \text { incorporated at } 70 \mathrm{DAS}+ \\
75 \% \mathrm{RDN})\end{array}$ & 87.80 & 15 & 23.01 & 111 \\
\hline $\mathrm{SE}( \pm)$ & 7.8166 & 1.0062 & 0.5069 & 6.5497 \\
\hline $\mathrm{CV} \%$ & 16.79 & 13.25 & 3.89 & 11.17 \\
\hline $\mathrm{P}$ value & 0.113 & 0.085 & 0.104 & 0.112 \\
\hline
\end{tabular}

$\mathrm{GM}=$ Green manure; RDN = Recommended dose of nitrogen; SE = Standard error of means; CV = Coefficient of variation 
Table 2. Residual effects of green manure and different levels of nitrogen on grain and straw yields of BRRI dhan28

\begin{tabular}{|c|c|c|c|c|}
\hline \multirow[t]{2}{*}{ Treatments } & \multicolumn{2}{|c|}{ Grain } & \multicolumn{2}{|c|}{ Straw } \\
\hline & $\begin{array}{c}\text { Yield } \\
\left(\mathrm{kg} \mathrm{ha}^{-1}\right)\end{array}$ & $\begin{array}{l}\% \text { increase } \\
\text { over control }\end{array}$ & $\begin{array}{c}\text { Yield } \\
\left(\mathrm{kg} \mathrm{ha}^{-1}\right)\end{array}$ & $\begin{array}{l}\text { \% increase } \\
\text { over control }\end{array}$ \\
\hline $\mathrm{T}_{0}(\mathrm{No} \mathrm{GM}+100 \% \mathrm{RDN})$ & 4208 & - & 4352 & - \\
\hline $\begin{array}{l}\mathrm{T}_{1}(\mathrm{GM} \text { incorporated at } 40 \mathrm{DAS}+ \\
50 \% \mathrm{RDN})\end{array}$ & 4233 & 0.59 & 4493 & 3.23 \\
\hline $\begin{array}{l}\mathrm{T}_{2}(\mathrm{GM} \text { incorporated at } 40 \mathrm{DAS}+ \\
75 \% \mathrm{RDN})\end{array}$ & 4814 & 14.4 & 4935 & 13.39 \\
\hline $\begin{array}{l}\mathrm{T}_{3}(\mathrm{GM} \text { incorporated at } 50 \mathrm{DAS}+ \\
50 \% \mathrm{RDN})\end{array}$ & 4395 & 4.44 & 4785 & 9.94 \\
\hline $\begin{array}{l}\mathrm{T}_{4}(\mathrm{GM} \text { incorporated at } 50 \mathrm{DAS}+ \\
75 \% \mathrm{RDN})\end{array}$ & 4966 & 18.01 & 5332 & 22.51 \\
\hline $\begin{array}{l}\mathrm{T}_{5}(\mathrm{GM} \text { incorporated at } 60 \mathrm{DAS}+ \\
50 \% \mathrm{RDN})\end{array}$ & 4534 & 7.74 & 4761 & 9.39 \\
\hline $\begin{array}{l}\mathrm{T}_{6}(\mathrm{GM} \text { incorporated at } 60 \mathrm{DAS}+ \\
75 \% \mathrm{RDN})\end{array}$ & 4418 & 4.99 & 4918 & 13.00 \\
\hline $\begin{array}{l}\mathrm{T}_{7}(\mathrm{GM} \text { incorporated at } 70 \mathrm{DAS}+ \\
50 \% \mathrm{RDN})\end{array}$ & 4313 & 2.49 & 4918 & 13.00 \\
\hline $\begin{array}{l}\mathrm{T}_{8}(\mathrm{GM} \text { incorporated at } 70 \mathrm{DAS}+ \\
75 \% \mathrm{RDN})\end{array}$ & 4967 & 18.03 & 5359 & 23.13 \\
\hline $\mathrm{SE}( \pm)$ & 253.37 & - & 336.65 & - \\
\hline $\mathrm{CV} \%$ & 9.76 & - & 12.04 & - \\
\hline P Value & 0.098 & - & 0.284 & - \\
\hline
\end{tabular}

$\mathrm{GM}=$ Green manure; RDN = Recommended dose of nitrogen; SE = Standard error of means; CV = Coefficient of variation

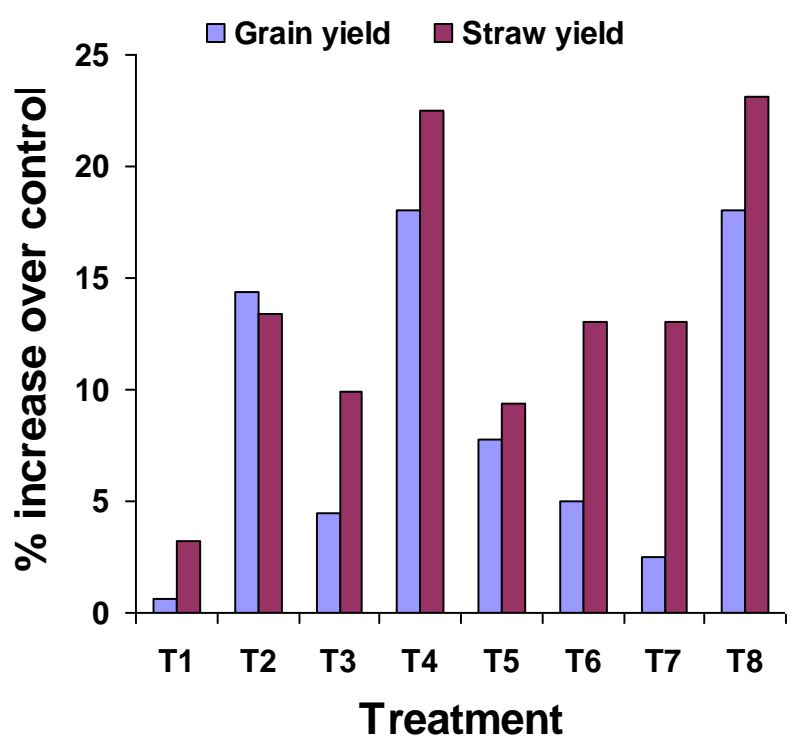

Fig. 1. Residual effects of green manure with different doses of recommended $\mathrm{N}$ on $\%$ yield increase over control 
Table 3. Residual effects of green manure and different levels of $\mathrm{N}$ uptake by BRRI dhan 28

\begin{tabular}{|c|c|c|c|}
\hline \multirow[t]{2}{*}{ Treatments } & \multicolumn{3}{|c|}{ N uptake $\left(\mathrm{kgha}^{-1}\right)$} \\
\hline & Grain & Straw & Total \\
\hline $\mathrm{T}_{0}(\mathrm{No} \mathrm{GM}+100 \% \mathrm{RDN})$ & $54.03 \mathrm{bc}$ & $33.45 \mathrm{bcd}$ & 87.49abcd \\
\hline $\begin{array}{l}\mathrm{T}_{1}(\mathrm{GM} \text { incorporated at } 40 \mathrm{DAS}+ \\
50 \% \mathrm{RDN})\end{array}$ & $44.62 \mathrm{c}$ & $27.70 \mathrm{~cd}$ & $72.32 \mathrm{~d}$ \\
\hline $\begin{array}{l}\mathrm{T}_{2}(\mathrm{GM} \text { incorporated at } 40 \mathrm{DAS}+ \\
75 \% \mathrm{RDN})\end{array}$ & $55.78 \mathrm{ab}$ & $35.61 \mathrm{ab}$ & $91.40 \mathrm{abc}$ \\
\hline $\begin{array}{l}\mathrm{T}_{3}(\mathrm{GM} \text { incorporated at } 50 \mathrm{DAS}+ \\
50 \% \mathrm{RDN})\end{array}$ & $53.10 \mathrm{bc}$ & $33.92 b c$ & $87.01 \mathrm{bcd}$ \\
\hline $\begin{array}{l}\mathrm{T}_{4}(\mathrm{GM} \text { incorporated at } 50 \mathrm{DAS}+ \\
75 \% \mathrm{RDN})\end{array}$ & $64.19 \mathrm{a}$ & $38.61 \mathrm{ab}$ & $102.81 \mathrm{a}$ \\
\hline $\begin{array}{l}\mathrm{T}_{5}(\mathrm{GM} \text { incorporated at } 60 \mathrm{DAS}+ \\
50 \% \mathrm{RDN})\end{array}$ & $48.29 \mathrm{bc}$ & $25.94 d$ & $74.22 \mathrm{~d}$ \\
\hline $\begin{array}{l}\mathrm{T}_{6}(\mathrm{GM} \text { incorporated at } 60 \mathrm{DAS}+ \\
75 \% \mathrm{RDN})\end{array}$ & $53.17 \mathrm{bc}$ & $39.27 \mathrm{ab}$ & $92.44 a b c$ \\
\hline $\begin{array}{l}\mathrm{T}_{7}(\mathrm{GM} \text { incorporated at } 70 \mathrm{DAS}+ \\
50 \% \mathrm{RDN})\end{array}$ & $48.52 b$ & $31.79 \mathrm{bcd}$ & $80.31 \mathrm{~cd}$ \\
\hline $\begin{array}{l}\mathrm{T}_{8}(\mathrm{GM} \text { incorporated at } 70 \mathrm{DAS}+ \\
75 \% \mathrm{RDN})\end{array}$ & $56.80 \mathrm{ab}$ & $42.42 \mathrm{a}$ & $99.22 \mathrm{ab}$ \\
\hline $\mathrm{SE}( \pm)$ & 3.01 & 2.33 & 4.64 \\
\hline $\mathrm{CV} \%$ & 9.82 & 11.77 & 9.20 \\
\hline P Value & 0.014 & 0.002 & 0.003 \\
\hline
\end{tabular}

Figure (s) in a column having common letters do not differ significantly.

$\mathrm{GM}=$ Green manure; RDN = Recommended dose of nitrogen; $\mathrm{SE}=$ Standard error of means; CV = Coefficient of variation

\section{Conclusions}

Green manure exerted significant residual effect on grain $\mathrm{N}$ uptake, straw $\mathrm{N}$ uptake and total $\mathrm{N}$ uptake of BRRI dhan28. The residual effect of green manure was higher in producing rice yields in treatments with the application of $75 \%$ of recommended $N$ fertilizer with green manure incorporated at 50 or 70 DAS. So it can be concluded that application of Sesbania green manure can reduce $25 \%$ of recommended $\mathrm{N}$ for BRRI dhan 28 cultivation. The experiment was practiced in the Old Brahmaputra Floodplain for profitable rice cultivation. However, more study is needed to confirm the results in other AEZs of Bangladesh.

\section{References}

BARC (Bangladesh Agricultural Research Council). 2012. Fertilizer Recommendation GUIDE-2012. Soils Pub. No. 45 Bangladesh Agricultural Research Council, Farmgate, Dhaka.

Bin, J. 1983. Utilization of green manure for raising soil fertility in China. Soil Science, 115:65-66.

BRRI (Bangladesh Rice Research Institute). 1998. Proceedings of the Annual Internal Review for
1997. Rice Farming Systems, BRRI Joydebpur, Gazipur. Pub. No. 1701. 60p.

Choudhury, A. T. M. A. and Khanif, Y. M. 2009. Effect of nitrogen, copper and magnesium fertilization on yield and nutrition of rice. Pakistan Journal of Science and Industrial Research, 45(2):102-107.

DAE (Department of Agriculture Extension). 2010. Agriculture in Bangladesh at a glance, Panya Nirdeshika, Khamarbari, Farmgate, Dhaka.

Dekamedhi, D. and Medhi, D. N. 2000. Effect of green manures and urea on nitrogen mineralization in relation to growth of rice under upper Brahmaputra valley zone of Assam. Indian Journal of Agricultural Science, 70(5):829-830.

Dreyfus, B.; Rinauda, G. and Dommergues, Y. 1985. Observation on the use of Sesbania rostrata as green manure in paddy fields. Journal of Applied Microbiology and Biotechnology, 1:111-121.

Evans, D. O. and Rotan, P. P. 1986. Role of Sesbania in Agriculture. West View Press, Boulder, Colorado. $192 \mathrm{p}$.

Elfstrand, S.; Båth, B. and Mårtensson, A. 2007. Influence of various forms of green manure 
amendment on soil microbial community composition, enzyme activity and nutrient levels in leek. Applied Soil Ecology, 36:70-82.

Ghosh, A. 2007. Comparative study on combined and individual effects of farmyard manure and green manuring with fertilizer $\mathrm{N}$ on growth and yield of rice (Oryza sativa) under submergence-prone situation. Indian Journal of Agronomy, 52(1):43-45.

Gu, R. S. and Wen, Q. X. 1980. Cultivation and application of green manure in paddy field of Chains. Proceedings of Symptom on Paddy Soil, pp. 207-219.

Glaser, B.; Lehman, J.; Fuhrboter, M.; Soloman, D. and Zech, W. 2001. Carbon and nitrogen mineralization in cultivated and natural savanna soils of Northern Tanzania. Biology of Fertilizers and Soils, 33:301309.

Gomez, K. A. and Gomez, A. K. 1984. Statistical Procedures of Agricultural Research. $2^{\text {nd }}$ ed. John Wiley \& Sons. New York. pp. 207-215.

Hossain, M. B. 2013. Contribution of green manure incorporated in combination with nitrogen fertilizer in rice production. MS thesis, Department of Soil Science, BAU. pp 51-54.

Jahan, M. B. 2014. Effect of pre-rice green manuring on the growth and yield of BINA dhan7. MS thesis, Department of Soil Science, BAU. 46-53.

Kumar, M.; Yaduvanshi, N. P. S. and Singh, Y. V. 2012. Effects of Integrated Nutrient Management on Rice Yield, Nutrient Uptake and Soil Fertility Status in Reclaimed Sodic Soils. Journal of Indian Society of Soil Science, 60(2):132-137.

Lee, C. H.; Park, K. D.; Jung, K. Y.; Ali, M. A.; Lee, D.; Gutierrez, J. and Kimd, P. J. 2010. Effect of Chinese milk vetch (Astragalus sinicus L.) as a green manure on rice productivity and methane emission in paddy soil. Agriculture, Ecosystems and Environment, 138:343-347.

Medhi, B. D.; Barthakur, H. P. and Barthakur, S. N. 1996. Effect of organic and inorganic source of nitrogen in the nutrients in soil and soil solution and growth of rice. Journal of Indian Society of Soil Science, 44(2):263- 266.

Nur E-Elahi, M. 1991. Intercropping forage green manure with a grain legume in the pre rice dry wet period for food, feed and organic nitrogen across irrigated and rain fed rice ecosystems. Rice Abstract, 15(2):92.

Paturde, J. T. and Patankar, M. N. 1998. Effect of green manuring with Sesbania rostrata and Sesbania aculeata as well as levels nitrogen on yield of transplanted paddy variety SKL-7. Agricultural Science Digest, 18(3):213-216.

Pypersa, P.; Verstraete, S.; Thi, C. P. and Merckx, R. 2005. Changes in mineral nitrogen, phosphorus availability and salt-extractable aluminium following the application of green manure residues in two weathered soils of South Vietnam. Soil Biology and Biochemistry, 37:163-172.

Singh, R. P.; Yadav, P. K.; Singh, R. K.; Singh, S. N.; Bisen, M. K. and Singh, J. 2006. Effect of chemical fertilizer, FYM \& biofertilizer on performance of rice \& soil properties. Journal of crop Research, 32(2):283-285.

Singh, S. P.; Devil, B. S. and Subbiah, S. V. 1998. Effect of nitrogen levels and lime application on grain of hybrid rice. International Journal on Rice, 23(1):25-26.

Singhabutra, N.; Arunin, S. and Anuluxtipan, Y. 1987. Experiment on two Rhizobium strains for inoculation into Sesbania spp. used as green manure on the reclamation of saline soil. Paper presented at the $25^{\text {th }}$ Annual Technical Meeting held from 2-6 Feb 1986. Kaset Start University, Bangkok.

Tiessen, H. D.; Cuevas, E. and Chacon, P. 1994. The role of organic matter in sustaining soil fertility. Nature (London), 371:783-785.

Thorup-Kristensen, K.; Magik, J. and Jensen, L. S. 2004. Catch crops and green manure as biological tools in nitrogen management in temperate zones. Advances in Agronomy, 79:227-302.

Warren, G. P. 1992. Fertilizer phosphorus sorption and residual value in tropical African soils. NRI Bulletin 37, Chatam, U. K. Natural resources Institute, pp: 89. 